\title{
THE PROBLEM OF PROVING FOREIGN LAW
}

\author{
BY ARTHUR NUSSBAUM†
}

\author{
The Fact Theory. Judicial Notice
}

THE phrase "foreign law is a fact," or "foreign law must be proved as a fact," is well known both in common law countries ${ }^{1}$ and on the Continent," and traceable back at least to the eighteenth century. ${ }^{3}$ During the last century this "fact" theory has lost much of its popularity in civil law countries, but in America and in other common law jurisclictions it still dominates cases, ${ }^{4}$ legislation, ${ }^{5}$ and literary discussion. ${ }^{\text {" In- }}$ deed, Professor Beale has recently called the fact theory "the fundamental premise" underlying the rules for proving foreign law.

Each law can be considered as a fact insofar as it is a controlling force in society; but when law and fact are contrasted, foreign law is, of course, law. However, foreign law is not always on equal terms with the law of the forum. Although courts are expected to know their own law, they cannot be expected to know the law of other countries. Hence litigating parties must prove the applicable foreign law to the court.

$\dagger$ Research Professor of Public Law, Columbia University.

1. See, e.g., Church v. Hubbard, 2 Cranch 187 (U. S. 1804); Nasima Sav. Bank v. Anglo-American Co., 189 U. S. 221 (1903); Los Angeles Inv. Scc. Corp. v. Joslyn, 12 N. Y. S. (2d) 370 (Sup. Ct. 1939) ; Guaranty Trust Co. v. Hanuay \& Co. [1918] 2 K. B. 623,667 (C. A.); Lazard Bros. v. Midland Bank [1933] A. C. 289, 297 (H. L. 1932) ; Roscoe, Evidence (Henderson's 20th ed. 1934) 86, 121; DiCEY-Ketri, Conflict of Laws (5th ed. 1932) 860; Cheshire, Conflict of Laws (2d ed. 1938) 129.

2. For citations from German, French and Italian Literature see Bossunkd, Dit: Aufgabe des Richters bei der Anwendung des Ausländischen Rechits (1929) 12. Many earlier cases, principally Latin, are listed in LA Locigin, LA EsEcuzione delLE Sentenze Straniere (1902) 307, n. 1. See Langenbeck, Bciträge sur Lc'llre von Bcwcise fremder Rechte vor inländischen Gerichten (1858) 41 ARCHIV Füh pt: Civilistiscute PrAXIs 129.

3. It appears, e.g., in Mostyn v. Fabrigas, 1 Cowp. 161, 174 (K. B. 1774); and in Prussia: Aligemeine Gerichtsordnung für de Preussichen Stanten (1793) part I, tit. 10, \$53. Lessona, La prenve des lois étrangères (1895) 27 RevuE DE DR. INT. 1:T de. Legislation Comparée 545, 547 cites Paciano, Cui Incumbat Onus Prounndi (Francos 1631) bk. 1, c. lxvi, no. 51 as asserting that foreign law must be proved by the parties.

4. See, e.g., Surgan v. Parker, 181 So. 86 (La. App. 1938); Alexander v. Gray, 181 So. 639 (La. App. 1938); Nickles v. Fenner \& Beane, 59 Ohio $\Lambda_{\text {pp. } 33,17}$ N. E. (2d) 283 (1938) ; Copeland v. Craig, 193 S. C. 484,8 S. E. (2d) 858 (1940).

5. N. Y. CIv. Prac. Acr $\$ 391$, and other American statutes cited in Wignore, EVidENCE (3d ed. 1940) §2558, n. 1 (hereinafter cited as WigMoks).

6. See, e.g., Stumberg, Conflict of Laws (1937) 157; Goodricit, Conflict of LAws (1938) 194; authorities cited note 1 supra, note 7 infra.

7. 3 Conflict of Laws (1935) 1664. 
Since courtroom proof is generally limited to questions of fact, it is conceivable that in the minds of lawyers foreign law has become assimilated to fact.

The particular persistence and strength of the fact theory in common law countries seem to have an historical basis. English courts at first were unwilling to apply foreign law at all; they preferred to decline jurisdiction in foreign law cases. ${ }^{8}$ The idea that in a given situation the foreign law, for instance, the legal rate of interest in a foreign country, might be factually significant paved the way for a more liberal attitude in receiving evidence of foreign law, the rationale for which was expressed as follows by the United States Supreme Court: "Those [ foreign] laws pervade all transactions which take place where they prevail, and give them their color and legal effect."

The fact theory has encountered considerable opposition. On the Continent, it gave particular offense to the nineteenth century internationalist school. Savigny, the founder of this school, had proclaimed the doctrine that recognition of foreign legal systems is a corollary to the equality between nationals and foreigners demanded by the Law of Nations. ${ }^{10}$ Later writers, in the spirit of this conception, asserted that courts must take judicial notice of foreign law; that even where the foreign law is not pleaded, judges are under a duty to ascertain it through research of their own. ${ }^{11}$ This theory, which became dominant in continental literature, ${ }^{12}$ is dictated by high ideals, but it seems hardly practicable. The formidable burden it throws upon the courts is dispro-

8. See discussion of early English cases in Sack, Conflict of Lazes in the History of English Law in 3 LAw: A Century of Progress (1937) 342, 387, 388.

9. Royal Arcanum v. Green, 237 U. S. 531 (1915). See also Gray v. Gray, 87 N. H. 82, 87, 174 Atl. 508, 510 (1934) : “. . . a part of the facts consists in the law under which the transaction took place." Of course, domestic law similarly gives "color" to domestic transactions but this color is not perceived because it does not stand out against its environment.

Undiscerning adherence to the "fact" theory has even led to the proposition that foreign law must be determined by the jury, although this body is obviously unfit for this intricate judicial task. Wigsrore $\$ 2558$; Comment (1932) $30 \mathrm{Mrrcu}$. L. Rev. 747. This unsound extension of the "fact" theory has now been practically abandoned, and vill not be considered in this Article. Nor will there be considered the doctrine according to which mistake of foreign law is regarded as a mistake of fact. Wiluston, Co:irnacts (1937 ed.) § 1592 .

10. 8 Systex des Heutigen Rourischen Rechts (1S49) $\$ 348$ [tr. by Guthrie under the title Private International Law (1880) 69].

11. See Bosshard, op. cit. supra note 2 , at 40,63 , and writers referred to by LA LoGGIA, op cit. supra note 2, at 309, n. 1 ; cf. also cases cited infra notes 13, 14.

12. See, e.g., von Bar, Theorie und Praxis des INt. Privatrectits (1859) [tr. by Gillespie under the title Theory and Practice of Private Ist. Law (1892)] n. 37; 2 Laurent, Le Dr. Civil Int. (1881) 485; Pillet, Principes de Dr. Int. Prné (1903) 84; Methi, Das Int. Ctvilprocesseecht (1906) 134 ; Resolutions of the Institut de Dr. Int. in 1891 (1892) 11 ANNUATRE 330. 
portionate to whatever advantages the system possesses. This method has influenced the courts mainly in Germany ${ }^{13}$ and Holland ${ }^{14}$ where judges widely possessed a reading knowledge of foreign languages. Other continental tribunals have required the litigating parties to come forward with proof of the foreign law which they wish the court to consider. ${ }^{15}$

Although the common law countries have never taken much stock in the internationalist view of foreign law, a strong movement against the proof-by-the-party rule has developed in the United States on a different basis. Most of the foreign law questions in this country have arisen in commection with the law of a sister state rather than of a foreign country. In our national system, with its widespread communication facilities and extensive publication of legal materials, it seems quite tunnecessary to regard sister states as "foreign" states and to require that the laws of neighboring jurisdictions be proved by the cumbersome courtroom rules of evidence. In most cases, it will be quite easy for a reasonably well equipped American court to inform itself fully about the law of a sister state.

For this reason American jurisdictions in the last two decades have been shifting to legislation requiring the courts to take juclicial notice of the laws of the sister states. A Uniform Judicial Notice of Foreign Litw Act was promulgated in 1936 and so far has been adopted by eleven states. ${ }^{16}$ At least fourteen others have similar statutes of an independent

13. Jan. 30, 1889, 23 Entscheidungen des ReichsGerichts in Zivilsachen 33; March 23, 1897, 39 id. at 376; May 24, 1921, 102 id. at 214; Nov. 14, 1929, 126 id. at 202. This practice has been adopted by the Austrian Supreme Court in the jutgments of July 30, 1931, Die Rechtsprechung 1932, 1 (with informative annotation by Wahle); Nov. 18, 1931, id. 1932, 132.

14. Supreme Court of the Netherlands, April 8, 1927, Nederland'sche Jurisprudentic 1927, 1110; March 20, 1931, id. 1931, 890.

15. France: Court of Cassation, April 2, 1910, Journal de Dr. Int. 1910, 1200; Nov. 19, 1912, id. 1913, 583; earlier cases cited in BoQuel, DE L'ofrice dU Juge EN Matière d'Appltcatton des Lors Etrangères (thesis, Nancy, 1923) 92, 93. Excepted are French statutory provisions or treatises prescribing the taking of judicial notice; cf. 1 Pillet, Traite Pratique de Dr. Int. Prive (1923) 141. Italy: Court of Cassation, May 23, 1930, Foro Italiano 1931, I 968; Dec. 19, 1933, id. 1934, I 402; Jan. 29, 1936, id. 1936, I 1083. In Switzerland the rule has been embodied in cantonal legislation. Federal Tribunal judgment of Nov. 24, 1933,60 Amtriche Santmlung Il 433; Schnitzler, HandBuch des Int. Privatrechts (1937) 85. The cantonal Acts are binding upon the federal courts. In both Italy and Switzerland the court may apply foreign law which it knows, though there is no proof by the parties.

In its extreme form the internationalist doctrine disallows proof of forcign law by the parties, who, however, may informally collaborate with the court. Bossundd, of. cit. supra note 2 , at 63 .

16. Illinois, Indiana, Maine, Maryland, Minnesota, Montana, North Dalkota, Ohio, Oregon, Pennsylvania, South Dakota. 9 Uniform Laws Ann. (Supp. 1939) 88, gives the statutory citations. For an analogous Canadian development see WiGMore $\$ 2573$, n. 16. 
type, ${ }^{17}$ and in two states the judicial notice principle has been introduced by the courts. ${ }^{18}$ Very few of the larger states now abide by the old common law rule, and the federal courts take judicial notice of the laws of the various states. ${ }^{19}$ Most of the cases prior to 1920 were influenced by mechanical difficulties, now overcome, in the ascertainment of the law of sister states, and no longer represent the law on this subject. Unfortunately, nearly all treatises on the subject still discuss the proof of foreign law in terms of past principles, citing superseded cases as the present law and giving the new statutory development just the honor of mention. The Conflict of Laws Restatement ignores the judicial notice rule. $^{20}$

Much of the old law has, of course, been preserved. For example, adoption of the judicial notice rule does not imply that the parties are released from pleading the foreign law. ${ }^{21}$ Making an informal reference to foreign law during the course of hearings is not sufficient. ${ }^{22}$ Observance of rules of pleading is necessary, as the Uniform Act recognizes, so that the adverse party will have sufficient time for preparation of his defense. ${ }^{23}$ Still, where the judicial notice rule has been adopted, the

17. Arkansas, California, Connecticut, Georgia (GA. Code Axs. (Park Supp. 1926) \$5818), Massachusetts, Michigan, Mississippi, Missouri, New Jersey, Tennessee (TE:n:. CODE ANN. (Shannon 1917) \$5586), Virginia, West Virginia, Wisconsin. For statutory citations not given here see WIgarone $\$ 2573$, n. 16; for New York see note 26 infra.

18. Saloshin v. Houle, 85 N. H. 126, 155 Atl. 47 (1931). In In rc Holden's Estate, $110 \mathrm{Vt} .514,1 \mathrm{~A}$. (2d) 721 (1938) the judicial notice rule was applied, though it was erruneously based upon the Vermont proof of foreign statutes act, infra p. 1025. See, however, Hillmer v. Grondahl, 109 Vt. 388, 199 Atl. 255 (1938).

19. 3 BEALE, op. cit. supra note 7 , at 1686 . In respect to the law of foreign countrie, it may be hoped that the federal courts will follow the state rule in the spirit of Sampson v. Channell, 110 F. (2d) 754 (C.C. A. 1st, 1940).

20. Restatedient, Conflict of LAws (1934) $\$ 621$ states without qualification the proof-by-the-party rule. $\$ 621$, comment $d$ remarks that "several states" take judicial notice of the law of another state.

21. Silverman v. National Assets Corp., 12 A. (2d) 389 (Del. Ch. 1940); Prudential Ins. Co. of America v. Shumaker, 12 A. (2d) 618 (Afd. 1940); Smith v. Brown, 19 N. E. (2d) 732 (Mass. 1939); Greear v. Paust, 202 Mfinn. 633, 279 N. W. 568 (1938); Baker v. Sovereign Camp, 233 Mo. App. 13, 116 S. W. (2d) 513 (1938); Hiffer v. Calmac Oil Co., 10 N.Y.S. (2d) 531, 538 (Sup. Ct. 1939); In re Barclay's Estate, 1 Wash. (2d) 82, 95 P. (2d) 393 (1939). Contra: Tuttle v. Jockmus, 106 Conn. 683, 138 Atl. 804 (1927); Loranger v. Nadeau, 215 Cal. 362, 366, 10 P. (2d) 63, 65 (1932), (1936) 24 CAL. L. REv. 311; Suskin v. Hodges, 216 N. C. 333, 4 S. E. (2d) $\$ 91$ (1939). The pleading requirement is a familiar proposition of the earlier continental doctrine. See Langenbeck, op. cit. supra note 2, at 132, 134; row BAR, op. cil. stupra note 12, at n. 37. See also p. 1035 infra.

22. Esmar v. Haeussler, 341 Mio. 33, 115 S. W. (2d) 54 (1938) scmble.

23. Section 4 provides: "Any party may present to the trial court any admissible evidence of such [foreign] laws, but to enable a party to offer evidence of the [foreign] law or to ask that judicial notice be taken thereof, reasonable notice shall be given to the adverse parties either in the pleadings or otherwise." 
requirements as to pleading foreign law should be kept in bounds. It is unwarranted to demand, for instance, that the parties set out a foreign statute in haec verba. ${ }^{24}$

At the trial, the judicial notice rule does not mean that the parties have no burden of going forward with evidence of the foreign law. Some proof should be introduced. Just how much is necessary seems to be a question of convenience as between court and counsel. The question has been officially considered in Massachusetts. Members of the Massachusetts bar "seemed to think that the statute . . . shifted the whole burden of the question to the court." Thereupon the Judicial Council recommended that the courts adopt a rule making it the duty of counsel "to call to the attention of the court such authorities or other material relating to the question [of foreign law] as they wish the court to consider." ${ }^{25}$ The New York statute explicitly makes it the duty of the parties to go forward with some evidence of the foreign law; the court's own research is therefore merely supplementary. ${ }^{26}$ But this is not a material divergence from the general line of the judicial notice statutes and New York essentially belongs with the jurisdictions following the judicial notice rule. ${ }^{27}$

There are certain rather important distinctions among the states which have adopted the judicial notice rule. Most of the statutes, including the Uniform Act, are mandatory ("the court shall take judicial notice"); only a few are permissive. ${ }^{28}$ The Uniform Act and a majority of the individual state enactments confine judicial notice to the laws of sister states. ${ }^{20}$ An exception to this rule is Massachusetts, in which by a mandatory statute of 1926 the courts are required to notice judicially the laws of foreign countries ${ }^{30}$ - a requirement reminiscent of the conti-

24. As was required in Dawson v. Dawson, 224 Ala. 13, 138 So. 414 (1933); accord, Bennett v. Myres, 21 S. W. (2d) 943 (Mo. App. 1929). The forcign rule need only be stated specifically enough to substantiate the cause of action or defense pleated. The rigid rulings antedating the judicial notice statutes listed in Notc (1922) 18 A. L. R. 1197 can no longer be considered as controlling.

25. (1939) 24(4) Mass. L. Q. 8.

26. N. Y. Civ. Prac. Act, $\$ 391$; see Cherwien v. Geiter, 272 N. Y. 165,5 N. E. (2d) 185 (1936).

27. In Mencher v. Goldstein, 240 App. Div. 290, 269 N. Y. Supp. 846 (2d Dep't 1934); Smith v. Russo Asiatic Bank, 160 Misc. 417, 290 N. Y. Supp. 471 (Sup. Ct. 1936) ; Shaw v. Blainey, 154 Misc. 495, 277 N. Y. Supp. 466 (Mun. Ct. 1935) the courts denied any duty to take judicial notice of foreign law. In these cases the parties had not pleaded or proven foreign law at all, but this point was not discussed in the very broad language of the courts.

28. Michigan, New Jersey, New York, Tennessec.

29. See statutes cited notes 16,17 supra. The judicial notice rule is one of the few issues upon which American practice as to sister state laws and international conflict rules diverge.

30. Mass. Gen. Laws (Ter. ed. 1932) c. $233, \S 70$. 
nental internationalist theory. In fact, the Massachusetts law was enacted under the influence of a theorist, Professor James B. Thayer. ${ }^{31}$ It does not appear, however, that he was acquainted with the continental doctrine; he derived his ideal of coordinating domestic and foreign law from the impractical proposition that foreign law is just as much a fact as is domestic law. ${ }^{32}$ The Massachusetts Judicial Council called the enactment a "pioneer step which we believe to be in advance of any other English-speaking jurisdiction." "33 Apart from the fact that several states already had similar statutes, ${ }^{34}$ later events do not bear out this claim. The Uniform Act rejected the Massachusetts theory and limited its scope to jurisdictions in the United States. While the Massachusetts statute is praiseworthy for its extension of the judicial notice rule to foreign law in a state where library facilities are adequate for this task, it seems unfortunate that the rule has been cast in a mandatory form. The flexibility of the New York rule, which permits a court to notice the laws of foreign countries when it finds it convenient to do so, seems mucir more desirable. ${ }^{35}$

It thus appears that adoption of the judicial notice statutes has not eliminated the duty of the litigants to present evidence of foreign law; the statutes have merely supplemented and liberalized the practice at common law. But American courts, apart, perhaps, from a few New England states, ${ }^{36}$ have thus far failed to make even this linited use of their new powers despite the mandatory form of some of the enactments. Judicial conservatism has checkmated the legislative attempts at reform in this field by over-stressing pleading requirements and by other means. Neglect on the part of legal writers to analyze, appraise, and make familiar the new statutory law has contributed greatly to this unfortunate situation.

\section{Techniques of Proving Foreign Law}

If foreign law is to be regarded as a fact and hence subject to the rules of proof, it certainly must be proved by evidence of a sort vastly different from that which is employed to prove ordinary facts. But with only a

31. Precininary Treatise on Entinence (1898) 257; (1939) 24(4) Alass. L. Q. 8.

32. In Saloshin v. Houle, 85 N. H. 126, 130, 155 Atl. 47,50 (1931) Thayer's theory is used in order to review the lower court's findings on foreign law; see p. 1034 infro,

33. (1939) 24(4) MAss. L. Q. 8.

34. MIrss. Code ANn. (Hemingway, 1917) §735; VA. Cove Axx. (Arichic, 1936) $\$ 6192 \mathrm{a}$ (enacted in 1918).

35. The mandatory form of the rule, together with its extension to foreign countries, has been adopted by North Carolina. N. C. CoDE Axs. (1939) $\$ 1749$ a.

36. New Jersey and Michigan also have this "permissive" form of the rule; see note 17 supra. In Connecticut, at least, the judicial notice rule is of old standing. See Lockwood v. Crawford, 18 Conn. 360, 370 (1847). 
single venerable exception, ${ }^{37}$ the cases have tended to tie the methods of proof of foreign law to the Procrustean bed of the fact theory. The courts have insisted upon archaic methods of proof despite the vast improvements of the last fifty years in making legal sources available throughout the world.

In England, oral testimony by expert witnesses, the method used for proof of facts, still seems to be practically the only admissible form of evidence of foreign law. ${ }^{38}$ The English cases on the subject are largely concerned with the process of qualifying expert witnesses. Treatises on Evidence and on Conflict of Laws devote considerable space to this question, but the precedential value of the decisions is very slight, as whether or not a particular witness qualifies as an expert depends more or less on the surrounding circumstances. ${ }^{39}$ Originally, the best evidence rule required that written law be proven by the production of an authenticated copy of the statute or decree, ${ }^{40}$ but since the Sussex Peerage case ${ }^{41}$ it has not been necessary to produce an authenticated copy of foreign written law, oral proof by experts subject to cross-examination being regarded as preferable.

The development of methods of proof in the United States has been affected by the close legal and commercial relations existing between the various states. While American courts originally followed the old English rule which required authentication of foreign statutes, ${ }^{42}$ today, under recent state enactments, a copy of a statute or decree contained in an official publication ${ }^{43}$ or in a publication commonly recognized ${ }^{44}$ by the courts of sister states, is regarded as prima facie evidence of the foreign law. This rule is applied in almost all American jurisdictions, partictularly

37. De Bode's Case, 8 Q. B. 208, 250-254 (1845).
38. See 1 Roscoe, Evidence (Henderson's 20th cd. 1934) 121; Wigmone $\$ \$ 1271$, 2090a.

39. For the cases see WigmoRe $\$ \$ 564,690$.

40. WIGMoRe $\$ \$ 1271,2090 \mathrm{a}$. Authentication had to be made uncler the scal of the foreign nation; Church v. Hubbard, 2 Cranch 187, 237 (U. S. 1804); Hill v. Packard, 5 Wend. 375 (N. Y. 1830). In Chanoine v. Fowler, 3 Wend. 173 (N. Y. 1829) the French consul, testifying to French law, laid before the court a copy of the Code de Commerce furnished him by his government. This was held not to be receivable proof.

41. 11 Cl. \& Fin. 85,115 (H. L. 1844).

42. WIGMORE $\$ 1271$.

43. This phrase will be used in this article as an abbreviation for "printed books or pamphlets containing the foreign law and purporting to be printed or proved to have been published by the authority of the foreign jurisdiction." Uniform Proof of Statctes Act § 378; see N. Y. Civ. Prac. Act § 391.

44. This phrase will be used as an abbreviation for "publications proved to be commonly recognized in the foreign courts." UNIFoRM PRCOF of STATUTrs ACT §378, N. Y. Crv. Prac. Act § 391 .

Older cases tended to spurn the convenience offered by this rule (which in New York dates back to 1848). See Hynes v. McDermott, 82 N. Y. 41, 54 (1880). 
in those states which have adopted the Uniform Proof of Statutes Act of $1920 .{ }^{45}$ The Uniform Act, as well as several independent state statutes, ${ }^{46}$ has extended the rule of admissibility to the written law of foreign countries. The proof of unwritten law ${ }^{4 \pi}$ is still based on oral testimony, but several states provide that the printed case reports are to constitute prima facie evidence of the unwritten law. ${ }^{48}$ Under the language of the New York Act, a court taking judicial notice of foreign law is limited to the use of statute books and case reports, but there seems no doubt that the Act does not preclude the use of legal treatises and commentaries, for purposes either of evidence or of judicial notice. That the use of these works is permissible is now well settled, although their admissibility is based upon several diverse theories. ${ }^{20}$ Certainly there are no better guides for one seeking information on civil law than the leading treatises or, perhaps for German law, the leading commentaries. An American court would probably permit an expert witness to read from treatises in court, but texts might also furnish appropriate instrumentalities for judicial notice.

Oral testimony on foreign law in this country is supplied in much the same way as in England, except insofar as the English courts require the expert to be a professional lawyer or a person (such as a consul) whose occupation necessarily involves familiarity with the branch of law under examination. ${ }^{50}$ American tradition has been more liberal on this score ${ }^{51}$ because it has been more difficult in this country than in England to find the proper sort of experts on foreign law. The recent influx of continental lawyers to this country may tend to tighten the requirements. But the chief test of an expert's qualification should be the worth of the testimony which he presents. In many cases it would not do much

45. Alaska, Arizona, Hawaii, Idaho, Indiana, Kansas, Louisiana, Mfaryland, Michigan, Nevada, North Dakota, Ohio, Pennsylvania, South Dakota, Tennessee, Utah, Washington. For references see 9 UNIFORAr Laws Awn. (1940 Supp.) 230.

46. Alabama, Arkansas, California, Connecticut, Delaware, Florida, Georgi3, Illinois, Iowa, Kentucky, Maine, Mfississippi, Missouri, Nebraska, New Jersey, New York, North Carolina, Oregon, Rhode Island, South Carolina, Texas, Vermont, Wisconsin. For references see WigMoRE $\$ 1684$, n. 15.

47. N. Y. Crv. Prac. Acr $\$ 391$ speaks of the "unwritten or common lav." This coordination is not accurate in respect to Civil Law. Genseines Recist means the modernized Roman law in force in parts of Germany prior to the Codes; droit commun is simply the counterpart of droit particulier (special law).

48. N. Y. Civ. Prac. Acr \$391; Ilz. Rev. Stat. (1939) c. 51, \$4\$ (does not include reports of foreign countries); ОHIо CODE ANN. (Baldwin, 1940) $\$ 11499$.

49. WIGAYORE $\S 1697$ (b); see, e.g., Saloshin v. Houle, 85 N. H. 126, 132, 155 Atl. 47, 51 (1931) ("textbooks and treaties may be consulted").

50. See American and English cases listed in WIgarone $\$ \S 564,690 ; 3$ Beale, op. cit. supra note 7 , at $1673 f$.

51. Liberality has been statutory as well as judicial. See, e.g., Cᄉs Codz Crv. Proe. $\$ 1902$ (requiring merely that witness be skilled in the foreign law). 
harm to reserve decision on the issue of qualification until the alleged expert has shown the extent of his knowledge of the subject at hand.

With respect to written foreign law, the courts have been given power by recent statutes to dispense with oral testimony, ${ }^{52}$ but this power has scarcely been used in cases involving the law of a foreign country. It is perhaps understandable that the courts in those cases desire the thorough exegesis offered by the interplay of direct and cross examination. Yet judges, at least in New York, insist upon the introduction both of expert oral testimony and of the official or judicially recognized editions of foreign statutes. The latter requirement may often be unreasonable. In the province of civil law, official editions are tustally very difficult to procure, if they are available at all. But most civil law codes and statutes appear in private editions which can be much more easily obtained and which give the texts as accurately and much more conveniently than do the bulky official editions. Private editions, in fact, are the everyday tool of the continental lawyer, who only in exceptional cases turns to the official Law Gazettes. But one might question whether those private editions satisfy the American statutes' requirement of being "commonly admitted as evidence of the existing law" in foreign tribunals. ${ }^{53}$ In the English courts, on the other hand, the expert may testify from private editions of any sort. ${ }^{54}$ Professor Wigmore has recommended that matters of this sort be left to the general discretion of the courts. ${ }^{65}$ It seems quite conceivable that American courts could adopt the discretionary English rule without finding it necessary to alter the statutes now in force. ${ }^{58}$

Turning to the methods of proving foreign law employed on the Continent, we meet with an entirely different picture. It is true that sworn oral testimony by "doctores" is mentioned as an ultimate method of evidence of unwritten foreign law by as early a writer as the Italian, Peregrinus, ${ }^{57}$ and that many recent continental writers on proof of foreign

52. See, e.g., N. Y. Civ. Prac. Acr §391.

53. As a matter of fact, the statutory phrase is inapt for civil law literature, since, strictly speaking, the generally used editions-e.g., the leading German commentaries-are not "admitted as evidence of the existing law" by the foreign courts; rather they are employed so as to benefit from opinions and references given by the amotator's or commentators.

54. 1 Roscoe, Evidence (Henderson's 20th ed. 1934) 122.

55. WIGMORE $\S 1271$.

56. N. Y. CIV. PRAC. Act $\$ 391$, e.g., where it might be said that the mode of introducing presumptive evidence of written law, set forth in the first sentence, is not the only method.

In Masocco v. Schaaf, 234 App. Div. 181, 254 N. Y. Supp. 439 (3d Dep't 1931) a witness was permitted to rely on a private edition of the Italian Codice Civile, there being no objection by the parties.

57. 3 Consilia con. XI, $\S \S 27-37$, a work not available to the present writer. Peregrinus lived from 1530 to 1616 . The citation is taken from 1 Catellanis, IL Dimirto Int. Privato (2d ed. 1895) 341. 
law make mention of the admissibility of oral testimony, ${ }^{88}$ a principle recently confirmed by the Italian Court of Cassation. ${ }^{63}$ Yet despite the careful canvassing of cases by $\mathrm{La}$ Loggia ${ }^{\mathrm{CO}}$ and other authors, the present writer is not aware of a single continental case in which oral testimony was actually given. Fr. Stein, the leading commentator on the German Code of Civil Procedure, calls the hearing of experts on any kind of law "entirely improper" ("durchaus unangemessen"), since interpretation and application of rules of law are the exclusive province of the judge. ${ }^{61}$

Apart from the proof of the texts of foreign statutes, judgments, and treatises, written statements by authorities and experts form the normal means of furnishing continental evidence on foreign law. ${ }^{62}$ In modern times, statements by public officials have become more important. In 1877, Mancini, then Italian Minister of Justice, said in a frequently cited $^{63}$ parliamentary speech which represents the continental view: "The best way [to prove foreign law] is to present the text of the law, or rather a statement by competent authority which certifies the exact wording and its actually being in force."

58. Usually in questions of customary law, foreign or domestic. See, e.g., Mricano, Le Rôle du Juge dans L'Application des Lors Etrangères (thesis, Paris, 1907) 48; Bosshard, op. cit. stipra note 2, at 80; and particularly Mittermaier, Über den Betwois ausländischer Gesetze (1835) 18 ARCHIV fÜR DIE Crvilistısche Praxis 67. In civil law doctrine, customary law is considered as an extra-judicial product of socicty-a question of fact to be proved by witnesses. Anglo-American common law, however, can only be ascertained by juridical analysis; it presents, as was early recognized by Mittermaier, a different evidential problem. He refers to a Prussian Royal Ordinance of December S, 1819 instructing the courts to require as evidence of English law authentieated opinions of two English lawyers certified to be men of reputable standing.

59. Judgment of Jan. 24, 1936, Foro Italiano 1936, I 1083, regarding American law. The doubt expressed by Mittermaier, supra note 58 was not raised by the court.

The archaic "stipulated" oath by the party, a continental inheritance from Roman law, is generally held inapplicable to the proof of foreign law, as is proof by "admission" (confession). See, e.g., Fr. Stern, Zivilprozessonduvusg (Jonas' 14th ed. 1923) 1293; MIICARD, op. cit. supra note 58, at 36. An Amcriean counterpart is that a demurrer does not admit an allegation on foreign law. Finney v. Guy. 189 U. S. 335 (1903); Knickerbocker Trust Co. v. Iselin, 185 N. Y. $54,58,77$ N. E. 877,878 (1906). But see Comment (1906) 20 HARv. L. REv. 74.

60. Op. cit. sipra note 2 .

61. Fr. Stein, op. cit. supra note 59, at 844. Similar objections have been raised by Boques, stpra note 15, at 105 .

62. This practice, too, can be traced back to the times of Peregrinus. See note 57 supra.

63. Even judieitilly. See Appellate Court of Aquila, June 19, 1928, Rivista di Diritto Int. 1929. : 44 . Italian: courts have repeatedly applied the label of documentary evidence to 1.rut $f$ foreign law. Court of Cassation of Torino, April 23, 1884, quoted in 1 Frore, Dr. : $x$. Privé (195i) 206: Appellate Court of Genoa, Dec. 11, 1893, La Legge 1894, I 891 : Ltalinn Con:t $\because$. Cassation, Dec. 19, 1933, Foro Italiano 1934, I 402. 
Two types of official statements must be distinguished. In one situation, legislatures may authorize their consuls, or ministries of Justice or other governmental agencies, to furnish information on domestic law for use in foreign courts willing to accept such information in evidence; ;4 European governments have repeatedly bound themselves by treaty to confer such authority upon their ministries of Justice and to have their courts recognize statements of a similar agency of the other government. ${ }^{05}$ Secondly, courts may receive in evidence statements on foreign law by research institutes or foreign-service authorities of their ozvn country: for instance, Italian courts admit statements by Italian consuls concerning the law of the country of their mission. ${ }^{66}$ Statements of the second sort are frequently occasioned by direct requests from the court to the informing authority. In important cases, the parties will probably still submit opinions ("consultations," "pareres") by "doctores." ${ }^{07}$ In any case, the plastic nature of the civil law of Evidence permits easier adaptation to the needs of the individual case than is found in common law systems. There may be also active and even intensive research by the court, particularly in countries like Germany and Holland, which have fully accepted the principle of judicial notice. Judicial research of this sort may result in an informal and cooperative proceeding of great efficiency.

A comparison of the civil law and common law systems seems to show that the common law practice of admitting oral testimony, with an opportunity for cross examination, permits a more thorough investigation

64. See BossmaRd, op. cit. supra note 2, at 74; Rechtshilfeordinung fur Zivilsachen (1931) Preussisches Justizmintstertalblatt 302, $\$ 34$ and passim. Courts, except Swiss Courts, do not issue such statements. BossmaRd, op. cit. supra note 2, at 77. Art. 410 of the Code Bustamente, 2 NIBoyet \& GoulE, Recueil. DEs Textes Usuels de Dkoir INT. 508, provides for judicial statements on the text and interpretation of the laws of the country to which the court belongs.

A judgment of the Civil Court of Buenòs Aires, April 19, 1926, digested in (1929) Zeitschrift FUR Ausländisches UNd 'INT. Privatrecht 394, wisely holds that a foreign consul may deliver and authenticate the text of foreign laws, but has no authority to certify the validity or invalidity of a legal transaction.

65. German treaties of this type are listed in Nussbaum, Deutsches InTERNATIONales Privatrecht (1932) 100, n. 5; Italian treaties in Morel.l, It Diritro Processualle Civile Int. (1938) 57.

66. Appellate Court of Parma, Nov. 30, 1909, Rivista di Diritto Int. 1909, 482, Appellate Court of Aquila, June 19, 1928 id. 1929, 594. A statement on Moroccan law issued by the German Embassy in Madrid was used by the Reichsgericht, Dec. 13, 1911, 78 Entscheidungen in Zivilsachen 190. For other cases, see Micarid, op. cit. supra note 58 , at $52-54$.

67. Art. 409 of the Code Bustamente, supra note 64, provides that forcign law may be proved through authenticated attestations from two lawyers of the forcign country, an unsatisfactory rule strangely reminiscent of the Prussian Ordinance of 1819, supra note 58. Section 34 of the Prussian Rechtshilfeordning, cited supra note 64, points out that in most cases the German diplomatic or consular representative would be able to procure opinions from competent foreign legal experts. 
into the foreign law. But it is doubtful that this method leads to greater clarity. A remark of Judge Learned Hand seems applicable to many instances in which an expert on foreign law takes the stand: "The testimony of the expert was exceedingly confusing, not due to any fault of his, but inevitable because of the attempt to import into the French law the refined notion which pervades our own ..." "08 The difficulties inherent in all testimony on foreign law are greatly increased by the common law procedure which requires that the expert display a full command of the English language. A carefully prepared written statement by an expert on the foreign law, translated, if necessary, by an official translator, seems to be a much more satisfactory device for setting forth the foreign law. It is the writer's impression that under the present practice of the courts, skillful advocates may succeed in developing confusing divergencies between experts on purely verbal matters in situations where coherent and well-substantiated written opinions would eliminate all difficulties. Furthermore, the common law system is saddled with the difficulty of finding qualified experts who are available to testify; this difficulty increases with the distance of the place of trial from the great metropolitan centers, and is inversely proportional to the importance of the legal system involved; experts on Swiss, Bolivian or Iraq law are much rarer than those on English or German law. The cost of acquiring an expert may become extremely burdensome, a fact which imposes a heavy penalty for invoking the foreign law. ${ }^{\text {s }}$

American procedure approaches the continental system in cases in which written affidavits of foreign law are admitted into evidence. ${ }^{70} \mathrm{Now}$

68. Wood \& Selick v. Compagnie Générale Transatlantique, 43 F. (2d) 941,942 (C. C. A. 2d, 1930).

69. Letters Rogatory, little used, in any event, in relation to foreign countries, are not issued, it seems, for the purpose of ascertaining a foreign law. Among other obstacles, the absence of legal compulsion to make lawyers testify on their law may be a factor. If the foreign lawyer is willing to testify, Letters Rogatory are not needed. The right of a party to have the court designate a commissioner to take depositions on foreign law abroad was recognized in Boyer v. Kuerzi, 87 App. Div. 605, 84 N. Y. Supp. 563 (2d Dep't 1903), but the recent statutes raise the question whether this is still the law, at least where other means of evidence are available. On the latter point, see Geoghegan v. Atlas S. S. Co., 16 Daly 229, 10 N. Y. Supp. 21 (Com. PI. 1890). Actual use of such commissions does not appear from the cases. Deposition on foreign law before a United States consul abroad seems a workable method but is not employed because of legal uncertainties; see WIGMrore $\$ 1295$. The costs of a proceeding abrosd, which involves the retention of foreign counsel or heavy travelling expenses, will deter most litigants from this procedure.

70. See Tradesmen's Nat. Bank v. Cummings Bros., 157 Atl. 385 (N. J. 1931); Italiano v. Rosenbaum, 246 App. Div. 687, 284 N. Y. Supp. 177 (1st Dep't 1935); Stern v. S. S. Steiner, Inc., 12 N. Y. S. (2d) 44 (Sup. Ct. 1939). The writer understands that affidavits on foreign law are received in New York probate practice. CrzssiIRE, op. cit. supra note 1 , at 132 refers to expert evidence by affidavit without giving 
that foreign law can be judicially noticed, there seems to be no reason for objecting to a sworn or unsworn affidavit. Even prior to the judicial notice rule there was at least one reported case of unsworn statements by foreign legal experts being considered by an American court. ${ }^{71}$ The theory underlying this free admissibility, both here and in similar continental cases, may be that statements of foreign law form part of the pleadings and may, at least if uncontroverted, be utilized by the court.

But the civil law system of admitting statements by foreign governmental agencies does not seem to have been adopted in English or American courts. Attempts by Parliament to permit introduction of statements by foreign courts as evidence of foreign law have completely failed in practice. ${ }^{72}$ It should be emphasized, however, that resolute employment of the principle of judicial notice may offer an excellent medium for liberalizing the orthodox approach of American courts and make the process of examining foreign law more elastic and more efficient. ${ }^{73}$

\section{Findings on Foreign Law}

Beset with peculiar problems as is the process of gathering forcign law material, the process of drawing conclusions from that material may likewise require efforts beyond the judge's daily routine. He will have to demonstrate his analytical faculties in an unfamiliar and intricate situation. It is well known that in most cases the experts presented by the litigant parties hopelessly contradict each other. The judge will both have to balance the qualifications of the contending experts and determine the point of foreign law on the basis of juridical appraisal. Where the testimony of one side is uncontroverted, English law, still influenced by the fact theory, places limitations upon the court's right of independent scrutiny ${ }^{74}$ which do not exist in American law. Adoption of the principle

particulars. Wigmore does not mention the matter. Sec also McRae v. Mattoon, 10 Pick. 49, 55 (Mass. 1830).

71. Gould v. Gould, 119 Misc. 845, 192 N. Y. Supp. 572 (Sup. Ct. 1922) (a former French Premier, Viviani, was among the experts).

72. British Law Ascertainment Act, 1859, 22 \& 23 Vicr., c. 63; Foreign Law Ascertainment Act, 1861, 24 \& 25 VICT., c. 11. The 1859 Act has been used a few times in English-Scotch relations, but even here considerable difficultics have developed. Macomish's Ex'r v. Jones [1932] Sess. Cas. 208. See generally, DicEY-KEITH, op. cit. supra note 1 , at 862 .

73. Resort to judicial notice may be very helpful in circumventing rigid statements on admissibility made in prior cases. See, however, Smith v. Russo Asiatic Bank, 160 Misc. 417, 290 N. Y. Supp. 471 (Sup. Ct. 1936), cited supra note 27 and infra note 99.

74. The-judge is confined to the material referred to by the expert but he may examine the law in question to see if the expert's interpretation is proper. Russian Comm. \& Ind. Bank v. Comptoir d'Escompte de Mulhouse [1923] 2 K. B. 630, 643; CuEsurne, op. cit. supra note 1 , at 132 . 
of judicial notice means that the court can make its own independent juridical analysis; the New York and Uniform Law types of the judicial notice rule do not differ on this point. In addition, the judicial notice statutes, in permitting the courts to forego expert testimony on foreign written law, clearly imply that judges may use their own judgment in considering the language of statutes or other written law ${ }^{75}-a$ judicial power which has never been questioned on the Continent.

There have inevitably been a few instances in which courts, because of errors in translation or for other reasons, have made incorrect findings of foreign law. ${ }^{76}$ But another development has been far more serious: courts forced to apply foreign law under their Conflict of Laws rules have again and again avoided using an unwelcome foreign rule by reading into it arbitrary territorial and other sorts of limitations which removed the situation at bar from the range of the rule. 77

The question may even arise as to whether a forum may invalidate a foreign law. On Conflicts principles, the power of the forum is coterminous with the power of an ordinary law court of the foreign country. Consequently the forum may hold a foreign statute invalid on grounds which are determined judicially in the foreign law. This view has surprising results. It is possible, for instance, for a non-American court, applying American law, to declare an American statute unconstitutional as violating the due process clause. In a suit against the Austrian Government, based upon its American loan of 1930, tried before an Austrian court of first resort, the government relied on the American Joint Resolution of June 5, 1933, abrogating gold clauses. The claimant invoked the due process clause. The unfortunate Austrian court stated that the due process clause is merely constitutional law, not "substantive law"; and that for this reason the court could not consider it ${ }^{78}$ - a very

75. This has frequently been done. Instances of independent examinations of foreign law are Dougherty v. Equitable Life Assur. Soc., 266 N. Y. 71, 193 N. E. 897 (1934); Mioscow Fire Ins. Co. v. Bank of N. Y., 280 N. Y. 286, 20 N. E. (2d) 758 (1939), 49 Yale L. J. 324; Míasacco v. Schaaf, 234 App. Div. 181, 254 N. Y. Supp. 439 (3d Dep't 1931).

76. See Appellate Court of Douai, Jan. 27, 1925, Jour. Dr. Int. 1925, 398; 1 Frusinexstein, Int. Privatrecht (1926) 292; Lewald, Le Contrüle des Cours Suprénes sur lapplication des lois étrangères (1936) 57 ACADEAUE DE DR. INT., REc. uEs Cocns, 205, 280 ; Bosshard, op. cit. supra note 2, at 86 . Some of the judgments alleged, however, may be classed as debatable.

77. Instances are listed in Nussbaum, Pablic Policy and the Political Crisis in the Conflict of Law's (1940) 49 Yale L. J. 1027, 1039 al seq. See also Buchanan v. Rucleer, 9 East 192 (K. B. 1808) ; Central Hanover Bank v. Siemans \& Halske, 15 F. Supp. 927 (S. D. N. Y. 1936) [cf. Nussbauss, MONEY IN tBe LAW (1939) 491, n. 16]; Mount Albert Borough Council v. Australasian Temperance Soc. [1938] A. C. 224. Systematic scrutiny probably would yield many other cases.

78. Bezirksgericht Vienna, Inner District, March 1, 1934, Die Rechtsprechung 1934, \$2 with ann. by Wahle. 
obscure piece of reasoning indeed. ${ }^{79}$ Apparently the court, unable to find a sound legal argument, tried to escape, conte que contc, an action as presumptuous as invalidating the Gold Clause Resolution. This reticence on the part of the court is very laudable. Invalidation on constitutional grounds should be left to courts acting under the constitution in question. To this writer's knowledge, there has never been an instance of judicial invalidation of a foreign statute but this seems to be the result of judicial tact and expediency rather than of legal compulsion. ${ }^{80}$

A valid legal limitation upon the forum's power may restlt from the force of foreign judicial decisions. In the first place, it is obvious that a civil law (or any other) forum applying the rules of a common law legal system must respect the rule of precedent even though the forum itself does not possess such a rule. ${ }^{81}$ But even where the applicable foreign law is that of a civil law country, the forum must conform to the views of the foreign courts. Despite the lack of the rule of precedent, the decisions of the highest continental courts do practically set the coursc of the law in their respective countries. Those highest courts are extremely reluctant to change a "jurisprudence fixée" ("feststehende Rechtsprechung," "giurisprudenza constante"). Actually, the chief difference between civil law practice and stare decisis is that the former does not attribute authoritative effect to decisions of the appellate courts gencrally, but only to pronouncements of the highest courts.

The noted French writer, Pillet, asserted the view' that following foreign precedents "subordinates" the domestic courts to the foreign courts, thus impairing national independence. ${ }^{82}$ A strange outgrowth of the sovereignty complex! It is true that the sovereign state, through its Conflict of Laws norms, is free to prescribe or to prohibit the application of foreign law. To the extent, however, that the forum agrees to apply foreign law, a sound phase of the fact theory of foreign law displays itself. The "color" which the foreign law gives to a foreign transaction is a product of the actual conditions surrounding the transaction and should be given full respect by the forum. In the words of the Hague court, "It is French legislation as applied in France which really constitutes French law." 83 Common law courts, irrespective of starc decisis, naturally ascertain foreign law from the judgments of the foreign

79. Possibly the court took Verfassungsrecht (constitutional law) in the European sense as a part of public law not applicable under the rules of Private International Law.

80. For an extensive discussion of the problem see Niboyet, Qu'cst-ce que la loi étrangère aux yeux des juges d'un pays determiné (1928) REvUE DU DR. INT. ET DE Legislation CONPAREE 753.

81. This was recognized by the Appellate Court of Hamburg. Judgment of May 5, 1934, in Die Deutsche Rechtsprechung auf dem Gebiete des Int. Privatrecuts IM JAHRE 1934 (1935) 8.

82. 1 Traité Pratique de Dr. Int. Privé (1923) 153.

83. Cases of Serbian and Brazilian Loans, P. C. I. J., Ser. A, No. 20/21 (1929) 46. 
tribunals, ${ }^{84}$ and there are no instances of French courts having followed Pillet's advice. ${ }^{85}$ But in a number of cases, German and Austrian courts, interpreting foreign law more magisterially than judicially, have placed their conception of the foreign law above the opinion of the highest court of the foreign country. ${ }^{80}$ This practice has been especially prevalent in cases in which the pertinent statutes of the forum and the foreign country were uniform. But even in this situation, so important in the American set-up, the independence of foreign judicial developments should be respected. . $^{\text {t }}$

\section{Foreign Law in Courts of Review}

The technical difficulties involved in ascertaining foreign law make it desirable that there be judicial review of decisions of lower courts (a postulate which also furnishes an additional reason for removing the matter from the jury). In civil law countries, ordinary appellate courts may reexamine the whole case, facts and law, foreign law therefore presents no difficulty on this score. Difficulties arise in connection with the cassation and other civil law types of further appeal, such as the German "Revision." 88 These remedies are granted in order to relieve errors of law; it is around this topic that the law-fact controversy in civil law revolves. The reason for thus limiting the remedy is a desire to lighten the burden of the highest court by confining its duties to the establishment and maintenance of a uniform interpretation of the national laws, a view obviously based on the precedent-like effect of the decisions of the highest court. As a corollary to this policy, "cassation" and its equivalents do not lie against error in the application of foreign law. Other reasons have been asserted to support this result; the most important of these is that it is sufficient to have one appellate court review the

84. See Elmendorf v. Taylor, 10 Wheat. 152, 160-161 (U. S. 1825): “. . . no Court in the universe, which professed to be governed by prineiple, would, we presume, undertake to say, that the Courts of Great Britain, or of France, or of any other nation, had misunderstood their own statutes, and therefore erect itself into a tribunal which should correct such misunderstanding." Accord, in respect to courts of sister states, Los Angeles Inv. Sec. Corp. v. Joslyn, 12 N. Y. S. (2d) 370, 379 (Sup. Ct. 1939). Contra: Menard v. Goltra, 40 S. W. (2d) 1053 (Mo. 1931) ; Esmar v. Haeussler, 341 Mo. 33, 115 S. W. (2d) 54 (1938).

85. Pillet himself relies on Court of Cassation, Nov. 18, 1912, Sirey 1914, I 258 where the Appellate Court had advanced an independent interpretation of the German Civil Code. There was, however, no indication that German decisions had been discarded.

86. For examples, see Nussbauar, op. cit. supra note 65, at 99, n. 2 and 3.

87. For a sound approach see Appellate Court of Douai, Mfar. 7, 1901, Jour. Dr. Int. 1901, 180, validating an inaccurately dated Belgian will in accordance with the Belgian interpretation of $\$ 970$ of the Code Civil, although under the French interpretation of the same section the will was void.

88. For a lucid and carefully documented presentation see Lewald, loc. cit. suspra note 76; cf. also LA LoGGIA, op. cit. sipra note 2, at 183. 
foreign law. Continental internationalist doctrine, however, advocates extension of cassation to the foreign law, ${ }^{80}$ Austrian courts have permitted review of foreign law ${ }^{90}$ and, surprisingly, the doctrine has recently been adopted by the Italian Court of Cassation. ${ }^{01}$ However, the highest courts of France, Germany, the Netherlands, Belgium, and Switzerland have steadfastly refused to review questions of foreign law. ${ }^{22}$

In common law countries the review question is less momentous. In contradistinction to its extensive discussion in continental literature, there seems to be no discussion of the subject anywhere in common law learning except in a carefully reasoned New Hampshire case. ${ }^{03}$ English apathy toward this matter is easily explainable, as the law-fact distinction is of very little significance even in appeals to the House of Lords, which has limited the issues brought before it more through discerning self-limitation by the House than through any other factor. ${ }^{04}$ As the English tradition is widely followed by American appellate courts, reexamination of findings on foreign law generally presents as little a problem here as in England. But in several states, review by the highest court is ordinarily limited to questions of law. ${ }^{95}$ In New York and elsewhere, ${ }^{00}$ statutes expressly provide that a court's findings on foreign law (or a charge to the jury on this point) are subject to review on appeal; the New York Civil Practice Act requires the trial court to include the determination of foreign law in its findings, and it authorizes the appellate court to engage in independent research, in the same manner as the trial court. ${ }^{.7}$ The upper court should be able to conduct such research even in the absence of an express provision of the New York type. ${ }^{88}$ When the findings of foreign law are taken away from the jury and transferred to the trial court, it seems consistent to extend the privilege of reviewing the findings to the highest court. It is true that a statement of the highest court on a point of foreign law lacks the effect of precedent, not because foreign law is regarded as a fact, ${ }^{90}$ but because the rule of precedent has been

89. This is also Lewald's view, loc. cit. supra note 76.

90. Judgnients of Dec. 1, 1926, Die Rechtsprechung 1927, 17; July 6, 1934, id. 1934, 162; May 22, 1936, id. 1936, 124.

91. Judgment of July 8, 1931, Settimane della Cassazione 1931, 1517.

92. Lewald, supra note 76 , at 281.

93. Saloshin v. Houle, 85 N. H. 126, 155 Atl. 47 (1931).

94. See Attwood v. Small, 6 Cl. \& Fin. 232, 301 (H. L. 1835); BENTw1CH, PRIVx Council Practice (3d ed., 1937) 205.

95. See, e.g., N. Y. Civ. Prac. ACr $\$ 589$.

96. Uniform Judictal Notice of Foreign Laws Act $\$ 3$.

97. N. Y. Civ. Prac. Act \$391.

98. See Woodward's Appeal, 81 Conn. 152, 70 At1. 453 (1908); Tarbell v. Grand Trunk Ry., 96 Vt. 170, 118 Atl. 484 (1922); Saloshin v. Houle, 85 N. H. 126, 155 Atl. 47 (1931).

99. The fact theory has been referred to in this comnection in Smith v. Russo Asiatic Bank, 160 Misc. 417, 290 N. Y. Supp. 471 (Sup. Ct. 1936). In Lazard Brothers v. 
limited to domestic law for historical and policy reasons. Nevertlucless, statements by the highest court may very well be used in a later proceeding, at least through judicial notice. Of course, it would be equally: objectionable to liken foreign and domestic law to such an extent that a party could invoke the foreign law for the first time before a cuurt devoted exclusively to reviewing matters of law. The New York law obviates this result by permitting review only of the recorded findings of the lower courts on the foreign law. ${ }^{100}$ This provision seems wise because the submission of foreign statutes and cases to the appellate court actually amounts to an offer of new evidence, generally not admissible before courts of review. ${ }^{101}$

\section{FaIlure to Prove Foreign Law}

\section{The Presumption Theory}

The noted American case, Cuba Railroad i' Crosby, is authority for the view that where proof of foreign law is necessary to maintain a suit and has not been furnished, and any efforts made under the judicial notice rule have failed, the court may order a dismissal of the complaint. ${ }^{102}$ The plaintiff, an employee of the railroad, lost his hand through a defect in machinery after notifying the railroad of the defect and receiving assurance that it would be repaired. As no evidence was given of the law of Cuba, where the accident occurred, the complaint was dismissed. Apart from this case, there are few instances in which American courts have dismissed a complaint ${ }^{103}$ because of lack of proof of foreign law. ${ }^{104}$ In an

Midland Bank [1933] A. C. 289, the House of Lords held, as a rule of evidence, that the findings on the foreign law made in another case cannot be given judicial cognizance. It must be remembered that the judicial notice rule has not been adopted in England.

100. N. Y. Crv. Prac. Act $\$ 391$.

101. Lennon v. Cohen, 264 Mass. $414,421,163$ N. E: 63,67 (1928). The weight of authority, however, is to the contrary. Walker v. Lloyd, 295 Afass. 507,4 N. E (2d) 306 (1936); Hite v. Hite, 301 Mass. 294, 17 N. E. (2d) 176 (1938); Supreme Court of the Netherlands, April 8, 1927, Nederiand'sche Jurisprudentie 1927, 1110; Supreme Court of Austria, May 18, 1933, summarized in Giurisprudenza Comparata di Diritto Int. Privato 1934, 51. For earlier German cases see voN BAR, op. cir. sugro note 12, at n. 37, nn. 2 and 4; for a discussion of American cases see Comment (1928) 42 Hanv. L. REv. 130.

102. 222 U. S. 473 (1912) (opinion by Mr. Justice Holmes).

103. Or overruling a defense, as the case may be. In Astianian y. Dostumian, 174 Mass. 328, 54 N. E. 845 (1899) Mir. Justice Holmes dealt hypothetieally with a defense, an incident of which was the alleged omission of a protest required by foreign law. He pointed out that the defense would fail in the absence of evidence proving the foreign law.

104. Christie v. Cerro de Pasco Copper Corp., 214 App. Div. 820, 211 N. Y. Supp. 143 (2d Dep't 1925) (insignificant per curiam decision following Crosby case); Riley v. Pierce Oil Corp., 245 N. Y. 152, 156 N. E. 647 (1927), see note 108 infra; Rositzli v. Rositzki, 329 Mo. 662, 46 S. W. (2d) 591 (1931) and other interstate cases cited 
early English case, Male v. Roberts, the plaintiff brought assumpsit for money advanced to an infant in Scotland. ${ }^{105}$ The transaction would have been void under English law, except for so much as was used for "necessaries," but the plaintiff was non-suited by Lord Eldon because Scotch law, althoigh applicable, was not put in evidence by the plaintiff. ${ }^{100} \mathrm{~A}$ nonsuit decree was also rendered by the German Reichsoberhandelsgericht in a case where children of a Russian decedent were allegedly liable as heirs for the latter's debts under conditions apparently warranting the claim under German law; the court held Russian law, which was not proven, to control. ${ }^{107}$ In the American cases dismissal seems to go to the merits. ${ }^{108}$

The overwhelming majority of cases have avoided the loss involved in dismissal of the complaint or nonsuit, ${ }^{100}$ by the use of a variety of devices. Where both parties relied on the law of the forum, this fact has been used by American and foreign courts as a justification for applying the law of the forum, ${ }^{110}$ on the ground that the parties' conduct

infra. The possibility of "failure" for lack of proof is also indicated in Saloshin v. Houle, 85 N. H. 126, 134, 155 At1. 47, 50 (1931).

In re Hall, 61 App. Div. 266, 70 N. Y. Supp. 406 (3d Dep't 1901), cited in Kales, Prestmption of the Foreign Law (1906) 19 HARv. L. REv. 401, 408 and by other writers, is not a good example. The court invalidated a marriage, a rather remote incident of the litigation, on the basis of the applicable foreign law, rather than because proof of foreign law was lacking. Among continental writers, dismissal of the complaint is primarily advocated by LA LoGGra, op. cit. supra note 2, at 317 .

105. 3 Esp. 163 (Com. P1. 1800).

106. The case is misapprehended by Cheshire, Private Int. Law (2d ed. 1938) 216-217, where it is represented as a decision on the merits under English law.

107. Judgment of April 28, 1879, 25 ENTSCHEIdUNGEN dES RETCHISOBERHANDELSGERICHTS 53 (the court was the predecessor of the Reichsgericht).

108. Explicitly in the Riley case, supra note 104, referring to N. Y. Civ. PrAc. Acr $\$ 482$ which, however, authorizes the court in its discretion, to dismiss "without prejudice." In the absence of this useful rule, dismissal for lack of proof should be considered as going to the merits; dismissal for lack of pleading may be different, however.

109. Where the theory of a court of review implied dismissal because proof of foreign law was lacking, the case has sometimes been remanded to the lower court. Reichsgericht, Oct. 8, 1924, Warneyers Rechtsprechung 1925, 48; Austrian Supreme Court, July 30, 1931, Juristische Wochenschrift 1932, 2334; Supreme Court of the Netherlands, March 20, 1931, Nederland'sche Jurisprudentie 1931, 890. Sometimes a court refuses to contemplate the alternative of dismissal. Thus in Marsters v. Lash, 61 Cal. 622 (1882) the court felt that in the absence of proof of the foreign law, the court must "of necessity" resort to its own law.

110. Pauska v. Daus, 31 Tex. 67 (1868); Brown v. Wright, 58 Ark. 20 (1893); Watford v. Alabama \& Florida Lumber Co., 152 Ala. 178, 44 So. 567 (1907) ; cf. Smith v. Muncie Nat. Bank, 29 Ind. 158, 161 (1867). This view has particularly been insisted upon by the Swiss Federal Tribunal, judgments of May 8, 1915, 41 Amtucue SaxmLUNG II 268; Dec. 14, 1920, 46 id. II 493; May 9, 1923, 49 id. II 225; March 12, 1925, 51 id. II 34 ; Oct. 26, 1937, 63 id. II 383. The German Reichsgericht holds a different view, see cases cited infra notes 138, 140, but not infrequently deems the application of German 
implied their submission to the law of the forum. ${ }^{111}$ In a number of cases where there was no showing of reliance by both parties on the law of the forum, but foreign law had not been proved, the law of the forum was nonetheless applied as the only law before the court. ${ }^{112}$ The great majority of cases, however, have applied the law of the forum, in the spirit of the fact theory, by means of "presumptions." One presumption used, mechanical in its application and sweeping in its scope, is that, in the absence of proof of the foreign law, the court must assume that the foreign law is the same as the law of the forum. ${ }^{113}$ The alleged presumption is an obvious non sequitur and nothing but a crude fiction disguising the substitution of the law of the forum for the unproved or unascertainable foreign law. American courts prefer a more sophisticated type of presumption which may be summarized as follows: the law of a sister state or other common law country, if not proven, is presumed to be the same as the law of the forum. ${ }^{114}$ Although some jurisdictions do not extend this presumption to statutory provisions, or extend it only with qualifications, the presumption normally seems to extend to statutory law, ${ }^{115}$ with an uncertain exception for penalties and

law corroborated by the parties' reliance on German law. Judgments of Dec. 5, 1902, 53 ENTSCHEIDUNGEN IN Zivisachen 140; Dec. 18, 1920, 101 id. 143; Oct. 29, 1927, 118 id. 283 ; Mlay 19, 1928, 82 Scufrerts ARchiv 289. See also note 111 infra.

111. This theory is found particularly in the American eases, but see also Reichsgericht, Feb. 25, 1919, 95 EnTschemungen in ZrviLsachen 42; May 19, 1928, 82 ScUfFerts ARCHIV 289; Nov. 5, 1928, Juristische Wochenschrift 1929, 434 (implied submission to the law of the forum by the party favored by the foreign law).

112. Van Wyck v. Hiller, 4 Rob. 940 (La. 1842); Burgess v. Western Union Tel. Co., 92 Tex. 125, 46 S. W. 794 (1899) and a number of early Louisiana cases, such as Crozie v. Hodge, 3 La. 357 (1832) and Bonneau v. Poydras, 2 Rob. 1, 13 (La. 1842); cf. Peet v. Hatcher, 112 Ala. 514, 21 So. 711 (1896). The Reichsgericht, MIarch 23, 1897, 39 Entschetdungen IN ZivissacheN 376; June 26, 1900, Juristische Wochensehrift 1900, 589; Nov. 22, 1901, id. 1902, 36 has ruled, without resort to presumptions, that German law applies where the applicable foreign law cannot be asecrtained. For Swiss cantonal cases in accord, see BosshaRD, op. cit. stipra note 2, at 109. The French, Belgian and Italian cases cited by Darras in (1901) Jour. DR. INit. Prns 446 do not bear out the theory under consideration, and the California cases cited by Kales, sipro note 104 , at 411 , employ presumptions contrary to the author's statement.

113. See cases cited in 3 Beale, op. cit. sipra note 7, at 1680, nn. 1-7; Norris v. Harris, 15 Cal. 226, 254 (1860); Syme v. Stewart, 17 La. Ann. 73 (1865); Blethen v. Bonner, 53 S. W. 1016 (Tex. 1898). Zuricr Code Crv. Proc. (1913) $\$ 100$ provides that the court "having no certain knowledge of the forcign law, may assume the foreign law to be the same as the domestic law, unless a diversity is proved by the parties." Other Swiss cantons have similar provisions, Scrnitzler, Hannoucr ors Ixt. ProvatRECHTS (1937) S6. The presumption was also used in various earlier decisions of French and other Latin courts; see LA LoGGIA, op. cit. sipra note 2 , at $316, n$ n. 3.

114. For a detailed account see BeALe, op. cit. supra note 7, at 1675 ct seq.; Wigsone. \$2536; Von Mioschzisker, Prcsumptions as to Foreign Law (1926) 11 Mrmw. L. Rev. 1.

115. 3 BEALE, op. cit. stpra note 7, at 1683 seems to consider this the minority rule. In fact, listing a "representative decision" for each state, he cites nineteen states pro and 
forfeitures. Where the foreign law does not belong to the common law group, the presumption is not applied except in respect to "universally recognized fundamental principles of right or wrong in deciding between contending parties," 110 such as the obligation to carry out ordinary contracts. The latter idea has a few congeners in continental law, ${ }^{117}$ but otherwise the elaborate system of presumptions is entirely American.

The shortcomings of the presumption theory have been repeatedly demonstrated, particularly by Professor M. M. Bigelow and by the late Chief Justice of Pennsylvania, Robert von Moschzisker. ${ }^{118}$ Although the "sophisticated" form of the presumption doctrine is not so crude a fiction as its naive, sweeping form, it is still so unrealistic that it offends common sense. For this reason, the rule has resulted in much judicial vacillation and uncertainty. ${ }^{119}$ The view which excepts foreign statutory law from the presumption theory is particularly objectionable in that it represents the foreign common law system in point as thorotghly petrified and antiquated, ${ }^{120}$ but this view has been adopted by the Restatement. ${ }^{121}$

nineteen contra. Among the "contra" decisions, however, there are at least threc which enunciate the presumption as to "common law," but do not involve any statute: Loulisville and N. Ry. v. Southern Co., 237 Ky. 618, 36 S. W. (2d) 20 (1931) ; Rosenblatt v. Holstein Rubber Co., 281 Mass. 297, 183 N. E. 705 (1933); Cory v. Mass. Mut. Life Ins. Co., 54 R. I. 144, 170 Atl. 494 (1934). Furthermore, Trafton v. Garnscy, 78 N. H. 256, 99 Atl. 290 (1916), and Amos v. Kelley Co., 240 Mich. 257, 215 N. W. 397 (1927), rest on a finding that there was no foreign statute. Marchant v. Mead-Morrison Mfg. Co., 252 N. Y. 284,169 N. E. 386 (1929) seems not to be in point. While Harris v. White, 81 N. Y. 532, 544 (1880) considers the question as doubtful, two recent lower court decisions use the narrow rule. Bernstein v. Fuerth, 132 Misc. 343,229 N. Y. Supp. 791 (Mun. Ct. 1928); Shaw v. Blainey, 154 Misc. 495, 277 N. Y. Supp. 466 (Mun. Ct. 1935). According to Grow v. Oregon Short Line, 44 Utah 160, 138 Pac. 398 (1913) the weight of authority is in favor of the broader rule. Moreover, the judicial notice rule will henceforth in many cases obviate the disregard of statutes of sister states.

116. Parrot v. Mexican Cent. Ry., 207 Mass. 184, 194, 93 N. E. 590, 594 (1911).

117. The Reichsgericht has repeatedly assumed that contracts are interpreted the same way among all civilized nations, and has therefore interpreted foreign contracts in the same fashion as German ones. Judgments of (3.t. 30, 1907, 19 ZEITSCHNIFT FüR Int. Recht 238; March 24, 1909, 71 Entscheidungen In Zivilsachen 9; July 11, 1919, 96 id. 230. This view cannot be given unqualified approval. See Reichsgericht, Sept. 28, 1885, 16 ENTSCHEIDUNGEN IN Zivilsachen 338 (presumption that a certain rule on dissolution of corporations is universal).

118. Annotations to 2 Story, Conflict of Laws (Bigelow's 8th ed. 1883) 863a; Von Moschzisker, loc. cit. supra note 114.

119. A particularly puzzling feature is that the courts sometimes hold the "sophisticated" presumption doctrine inapplicable, only to resort to the "naive" form of the presumption. Norris v. Harris, 15 Cal. 226, 252 (1860); Peet v. Hatcher, 112 Ala. 514,21 So. 711 (1896).

120. In Reidman v. Macht, 98 Ind. App. 124, 183 N. E. 807 (1932) it was held that a Kansas promissory note was not negotiable because Kansas law was not proved and therefore common law applied. The Uniform Negotiable Instruments Law was adopted by Indiana in 1913 and by Kansas in 1905 .

121. Restatenent, Conflict of Laivs (1934) §623. 


\section{The Substantial Justice Theory}

In spite of the strenuous objections which may be made to the presumption theory, the policy of applying the law of the forum in the absence of proof of foreign law seems perfectly sound. Once the stumbling block of the presumption doctrine is renuved, both greater clarity of reasoning and betterment of a number of existing practices may lie expected.

As mentioned above, courts have sometimes applied the law of the forum when foreign law was not pleaded or proved, without resorting to a "presumption" or any other form of reasoning. The idea that, in the absence of proof of foreign law, the law of the forum is the only law before the court has a certain visual force, but it begs the questiun. Since foreign law would ordinarily be applied in these cases under the Conflicts rules, the answer must explain why resort to the law of the forum is preferred to dismissal of the action.

The opinion of the circuit court of appeals in the Crosby case points the way to the solution. The court applied to the Cuban situation "the law as the court conceives it to be, according to its idea of right and justice; or in other words, according to the law of the forum."120 Hence in order to do justice, the court gave judgment for the plaintiff. This was a far better method than dismissing the complaint, as the Supreme Court did, because Cuban law was not proved. Even if the theory of the Supreme Court in this particular case seems tenable, it can hardly be doubted that in the vast majority of situations the law of the forum will permit a perfectly reasonable disposition of the litigation. And the need to apply the lex fori is particularly strong in common law jurisdictions because of the difficulties and costliness involved in the cummon law proof of foreign law.

A situation in which the reasons for applying the law of the forum are particularly compelling is that in which neither of the parties has invoked the foreign law. It has been asserted judicially that parties cannot by agreement change the law applicable to their relationship. "An agreement is not a contract, except as the law says it shall be, and to try to make it one is to pull on one's bootstraps. Some law must impose the obligation, and the parties have nothing to do with that; no more than with whether their acts are torts or crimes." ${ }^{123}$ This familiar argument ${ }^{124}$

122. 222 U. S. 473,477 (1912).

123. Judge Learned Hand in Gerli \& Co. v. Cunard S. S. Co., 48 F. (2d) 115 (C. C. A. 2d, 1931).

124. See particularly 2 BeAle, Confuict of LAws (1935) 1079; on the other hand see W. W. Cook, Contracts and the Conflict of Law' (1938) 32 ILL. L. REv. 899. The same objection has long been advanced and refuted in continental literature. See, e.n. 2 Broctsfr, Cours de Dr. Int. Privé (18S3) 74: vos BAr, op. cil. supra note 12, at \$247. Compare Meijers, L'histoire des Principes Fondamenlaut, ete. (1934) 49 Acadearte de Dr. INT. Rec. des Cours 547, 634. 
0

is not convincing even in the conceptual sphere. Suppose that the legal rules governing a sales transaction, for instance, are the sort called in civil law "dispositive" rules, i.e., subject to alteration by the parties, and that the legal systems under contemplation agree in allowing the parties to alter those rules. There is no reason why the parties in fixing the terms of their contract should not be able to choose one legal system to the exclusion at least of the "dispositive" rules of another system. Public policy may forbid the parties to submit to a particular foreign law, but that is a decision which should be made as the particular situation arises, not on an a priori basis. In fact, in the field of contracts, both common law and civil law courts have frequently recognized the so-called "autonomy" of the parties, i.e., their right to select a law proper to their contract. ${ }^{125}$

Fortunately, the problem before us is narrower and less troublesome than the "autonomy" issue. We are not concerned with a contractual accord as to the law to be applied, but only with certain procedural behavior of the parties. Judicial language implying an "agreement" in these circumstances should not be taken too seriously. The important factor from the viewpoint of substantial justice is not a question of agreement but the reliance of the parties on the law of the forum. By placing themselves upon the parties' common ground, courts will satisfy both parties - a rare opportunity - and at the same time simplify the proceeding through eliminating the trouble of proving foreign law. This result is, therefore, much less disturbing than are the consequences of the autonomy theory which would ordinarily lead to the substitution of foreign law for the law of the forum. It is true that the Conflicts rule does not come into operation under such circumstances. But it should be realized that the parties may just as well submit their dispute to arbitrators who would pay little attention to the rules of the Conflict of Laws. ${ }^{120}$

On the other hand, there must be a limit to using the lex fori solely on the ground that the applicable foreign law was not pleaded or proved. One may assume a kind of counterpart to the "public policy" concept which, in exceptional cases, insists upon application of the lex fori. Similarly, there are situations in which application of the foreign law is required under all circumstances.

125. See cases cited in CheshiRe, op. cit. supra note 1, at 250 et seq.; StUMaERG, $o p$. cit. supra note 6, at 209 et seq. ; The King v. International Trustee [1937] A. C. 500, 529 (H. L.) : Vita Food Products v. Unus Shipping Co. [1939] A. C. 277 (P. C.), (1940) 40 CoL. L. Rev. 518; Bosemann v. Connecticut Gen. Life Ins. Co., 301 U. S. 196 (1937). For a list of civil law cases see Haudek, Die Bedeutung des Parterwillens im INT. Privatrecht (1931) 46.

126. This writer's long experience with arbitration has yielded only two cases in which arbitration tribunals discussed Conflicts problems: the award against the Soviet Government in the Lena Goldfield case, London Times, Sept. 3, 1930, and the Hamburg award reported in Hanseatische Rechts- und Gerichtsseitschrift 1931 B no. 142. 
One group of such situations relates to rights originating in fureign familial and inheritance relations. It hardly need be said that the foreign law governing divorce, or annulment of marriage, cannot be replaced by the lex fori merely because of failure to plead or to ascertain the foreign law. The same can probably be said of property litigation originating in familial and inheritance situations. Where personal property, belonging to a foreign decedent's estate, was found within the jurisdiction of the forum where it was claimed by an alleged representative of the decedent, an American court has held application of the lix fori tu be out of the question although there was no proof of foreign law. ${ }^{19 \pi}$ Nor was the court in the German case discussed above ${ }^{123}$ prepared to hold a person liable for debts of a deceased alien non-resident on the ground that he would be liable for these debts under German law. And where an illegitimate child sued his alleged father for maintenance in a Dutch court and the facts clearly indicated that Swiss law should control the situation, the Dutch court refused to render judgment for the plaintiff on the basis of Dutch law, even though Swiss law was not pleaded. ${ }^{129}$ These decisions are explained by the well-known disparities existing between the inheritance and maintenance laws of the various countries. There is the additional consideration in inheritance and familial cases that the judgment, in fact or in law, may have disturbing effects beyond the immediate objects of the litigation.

The consciousness of far-reaching disparities between local enactments may also lie behind the reluctance of American courts when, in wrongful death actions for wrong done abroad where the foreign law is not proved, they hesitate to resort to application of the local wrongful death statute $;^{130}$ the strength of the common law tradition disfavoring these actions might be another factor. ${ }^{131}$ American courts are also hesitant to inflict forfeitures or penalties in foreign situations under the law of the forum where there is no proof of the applicable foreign law. ${ }^{132}$

127. Leach v. Pillsbury, 15 N. H. 137 (1844). In this case the property was claimed by an attaching creditor of the alleged representative.

128. See p. 1036 supra.

129. Supreme Court of the Netherlands, March 20, 1931, Nederland'sche Jurisprudentie 1931, 890.

130. Even where the parties were apparently citizens of the forum. Ryan v. North Alaska Salmon Co., 153 Cal. 438, 95 Pac. 862 (1908); Rositzki v. Rositzli, 327 ג1o. 662, 46 S. W. (2d) 591 (1931). But cf. Grow v. Oregon Short Line, 44 Utah 160, 13S Pac. 398 (1913). 3 BeALE, op. cit. supra note 7, at 1684 camot be followed in remarling that the Rositzki case might well provide a foundation for overruling carlier cases to the contrary; see also Comment (1932) 10 Texx. L. Rev. 306.

131. This motive was explicitly referred to in MIurray's Adm'x v. Louisville \& $N$. Ry., 132 Ky. 336, 110 S. W. 334 (1908).

132. Harris v. White, 81 N. Y. 532,544 (1880); Westheimer v. Habinck, 131 Iowa 643, 109 N. IV. 189 (1906); Grow v. Oregon Short Line, 44 Utah 160, 138 Pac. 393 (1913). 
The individual views of the court will always constitute a major factor in the drawing of the borderline between what might be called the "absolute" and the "relative" foreign law cases, but they will not affect the validity of the basic conception: that in the absence of proof of the foreign law, and particularly in the absence of reference to foreign law by the parties, a court should apply its own law when substantial justice can thereby be attained. ${ }^{133}$

While this proposition retains, on the whole, the valuable results of judicial practice, the departure from the presumption doctrine is by no means merely theoretical. In the interstate area the stbstantial justice proposition coincides with the doctrine which applies the statutory law of the forum rather than foreign law. In the international field it liberalizes the rule which tries to restrict the use of the lex fori to "universally recognized fundamental principles of right or wrong." Instead, it would make application of the lex fori the principle whenever foreign law is not pleaded or not proved.

Another difference between the theories is in the matter of burden of proof. The presumption theory has been blamed for unduly shifting the plaintiff's burden of proof to the defendant. ${ }^{134}$ Where, for example, a foreign contract is valid under the law of the forum, an alleged invalidity flowing from the foreign law must be proved by the defendant, according to the presumption doctrine, although it is for the plaintiff originally to prove the existence of a valid cause of action. While it must be admitted that the inversion of the burden of proof which restlts from applying the presumption doctrine is too mechanical a solution, it is still not desirable to assume with some critics of the presumption theory that the burden of proof of foreign law invariably goes along with the burden of proving the original cause of action (or, in some cases, of proving the defense). Professor Beale, one of those who criticize the presumption doctrine, approves the Crosby case $^{135}$ in which the Court, refraining from any presumption, decided against the plaintiff becausc he had neglected to prove the Cuban law. But it is precisely this point which leaves the reader of the case with a particular feeling of dissatisfaction. ${ }^{136}$ It would have been easy for the Cuban Railroad to plead and

133. In Thompson v. Ketcham, 8 Johns. 146 (N. Y. 1811) a suit had been brought upon a promissory note executed in Jamaica by the defendant who was then not yct twenty-one years old. Chancellor Kent gave judgment for the plaintiff because the defendant, having failed to prove the law of Jamaica, had not made out his defense of infancy. The decision was perhaps actuated by a desire of the Chancellor to do "substantial justice" under the circumstances. Yet unless foreign law had been employed, substantial justice could only have been done within the bounds of the lex fori, which would have demanded the dismissal of the complaint.

134. Kales, supra note 104 , at $412 ; 3$ BEALE, op. cit. supra note 7 , at 1681.

135. Id. at 1678,1682 .

136. See Note (1912) 38 L. R. A. (N.s.) 40. 
prove the foreign law with respect to questions familiar to railway management. The fact that the company failed to do so gives rise to the surmise that the Cuban law favored the plaintiff. In such a situation it would be sound policy to expect the defendant to prove the foreign law. Application of American law rather than the harsh dismissal of the cumplaint would have been quite feasible and proper since all the partics were apparently Americans - a point immaterial from the viewpoint of the presumption doctrine, as well as under the rigid theory of the Cuurt, but important from the standpoint of substantial justice. ${ }^{13 \pi}$ Where the latter theory is employed, the burden of proof as to foreign law will depend entirely upon the circumstances of the case, and may be used as another flexible instrumentality for avoiding undesirable dismissals.

It is true that the continental internationalist doctrine is even more remote than the presumption theory from the point of view taken by the writer. This may be shown by a post-war German case which turned on a contract for the shipping of goods from Bolzano (Italy) to Kufstein (Austrian town at the German frontier). Neither the plaintiff, the Bolzano shipping firm, nor the defendant, a German citizen and resident, had pleaded foreign law. The Appellate Court decided the case on the basis of German law. The Reichsgericht reversed, directing that the case be disposed of on the basis of Italian law, solely on the ground that Bolzano was the "place of performance." There would be a point to the application of Italian law if, say, German law was not suited to a question of Alpine transportation. But such a question did not arise. ${ }^{135}$ It certainly could not be said that resort to German law was obviously unfair to the parties : the plaintiff himself had applied to German courts, without relying on non-German law, ${ }^{139}$ and the defendant was a German national and resident. The Reichsgericht's point was simply dictated by internationalist doctrine: the court as well as the parties had become the slave of some mysterious supranational ruler exacting strict obedience without pausing to consider the best interests of the parties as felt by themselves and by

137. Similar objections apply to the majority opinion in Riley v. Pierce Oil Corp., 245 N. Y. 152, 156 N. E. 647 (1927). Oil was allegedly converted in Mfexico by the defendant, an American corporation owning tremendous oil interests in Mexico; the plaintiff, too, was apparently an American. The complaint was dismissed because the plaintiff had not proved the Mexican law on conversion. Crane and Pound, IJ. dissented, because the action was based upon a "fundamental proposition" warranting, by" way" of presumption, the application of American law.

138. Judgment of Oct. 8,1924 , llarneyers Rechtsprechung 1925, 4S. The sections on transportation and many other matters in the German Commercial Code of 1897 are merely an amended edition of the General German Commercial Code of 1861, adopted also by Austria.

139. Except that the plaintiff had invoked the Austrian Commercial Code, then still in force in Bolzano, as the statute of limitation, but this point was not stressed by the court. 
the lower courts. ${ }^{140}$ To top it all, such obedience was demanded in the name of the place-of-performance theory of contracts, one of the most questionable issues in Private International Law.

Rejection of the internationalist view does not mean that freedom of courts from binding rules is advocated in all Conflicts situations. The writer does not agree with some distinguished American authors who, on the basis of a "local law theory," would determine the applicable law in each Conflicts situation according to the forum's own views on justice or on general social or economic policy. ${ }^{141}$ To the extent that Conflicts rules have evolved judicially or otherwise they must be obeyed in the same way as other rules of law. The present study is confined to the situation in which the applicable foreign law has not been proven. Under these circumstances the suggestion is that, except in a relatively small number of exceptional cases, the law of the forum should be applied, rather than the complaint dismissed. As the issue has been dominated by theories and slogans which are widely recognized as antiquated and confusing, recourse to fundamental principles has now become necessary. Such recourse may temporarily carry with it vagueness and uncertainty which, however, are equally apparent under the present erroneous doctrines. Should it be possible to reconstruct a sound juridical basis, one may hope that the courts will develop satisfactory precedents and thereby gradually develop a new certainty.

140. Similar views have been advanced by the Reichsgericht, Jan. $30,1889,23$ ENTSCHEtDungen IN ZiviLSACHEN 31, 34; May 24, 1921, 102 id. 214.

141. The "vested right" doctrine is incompatible with the "substantial justice" theory of the present Article as well as with the presumption theory. Either theory runs counter to the "territoriality" principle which connects the "vested right" with a given territory. It is for this reason that Professor Beale approves of the unsatisfactory tenets of the Crosby case and the Rositzki case, supra note 130. In fact, the proof-of-foreign-law situation furnishes another point against the vested right doctrine. 